\title{
Perceptions of key stakeholders regarding National Federation Sport Policy: The case of the French Rugby Union.
}

Bastien Viollet, University of Poitiers, France, bastien.viollet@univ-poitiers.fr

Brian Minikin, University of Stirling, UK

Nicolas Scelles, University of Stirling, UK

Alain Ferrand, University of Poitiers, France

\begin{abstract}
:
This article proposes a framework that explains how a national association sport policy is operationally formalised in relation with the various perceptions of its internal stakeholders. This is an important issue as a lack of engagement from these stakeholders may result in a limited impact of such a sport policy. Considering the latter as a management tool, a case study of the French Rugby Union (FFR) was built using archival material and interviews. We demonstrated that a national sport federation policy, when viewed as a management tool is the consequence of a conceptual framework, consisting of: a formal substrate, a managerial philosophy and a simplified representation of the actors' role (Hatchuel \& Weil, 1992). As part of an intervention-research within the FFR, 45 semi-structured interviews were conducted with both national and regional actors with various statutes. The analysis of these interviews shows both agreement and contradictions, categorized through the conceptual framework used to explain that a "one size fits all" approach should enable a degree of regional freedom for sport governing bodies that include organisational membership.
\end{abstract}

Keywords: sport policy, national sport federation, stakeholders, management tool, French Rugby Union.

Accepted for publication in Managing Sport and Leisure published by Taylor and Francis. 


\section{INTRODUCTION}

Do we want more players? Can our game be more appealing to female players? Should we have more community leaders? Do we need more clubs? What level do we aim for our national teams?

These questions are examples of issues for which appropriate strategies must be developed, based on the framework provided by an overriding policy (Bloyce \& Smith, 2010; Finlay, 2000). Such policies are derived, recognising the values of the organisation (Camy \& Robinson, 2007), and by understanding its internal and external environment and the capabilities and resources to deliver its derived objectives (Barney, 1991). For a national sport federation (NSF), the challenge is to be able to define how its sport is practiced in the future and what development it must undergo in order to achieve that practice. Therefore the processes that lead to the conception or formulation of a NSF sport policy by the actors located both at the headquarters and the regional committees that affiliate to it, needs to be better understood. Even though the concept of a sport policy has existed since the year 2000 (e.g. Houlihan, 2000), researchers in sport management have not investigated how these choices are made within a NSF, but rather treat it as a posteriori of the design process. Therefore, our starting point is about trying to conceptualise what is meant by a sport policy in the framework of a NSF. Using the concept of a management tool (David, 1998), a sport policy is considered as such and so this tool is the outcome of the link between three complementary elements (our conceptual framework), consisting not only of a formal substrate (content or documentation, 'what?'), but also a managerial philosophy (objectives or 'spirit', 'why?') and a simplified vision of the actors' role (context, 'who?') (Hatchuel \& Weil, 1992). ${ }^{1}$

The research presented by this article, examined the case of the French Rugby Federation (FFR) to determine, on the basis of the proposed conceptual framework, how its actors perceive its sport policy. The FFR is recognised as promoting public interest by the Ministry of Sport, and has undergone significant changes over the past 10 years, including professionalization of its activities, individuals, structures and processes (Nagel et al., 2015). As such, the FFR may be considered as representative of other French NSFs. In addition, the FFR has reached a plateau in its development, pushing it to commit to a reflection on its sport policy. This has been strengthened by the lack of impact of the FFR strategic project over the period 2009-2012, with insufficient communication and information sharing across actors having been identified as important factors so as to explain this (FFR, 2012).

A Top-Down approach to development as directed by a national sport policy, has some limitations (Skille, 2008) as each region has a specific environment in which it operates, while each organization has its own resources and capabilities with which it can deliver developmental objectives (Gregory \& Chapman, 2012). The approach of this study is to determine how national and regional actors may collaborate to develop a sport policy which can be understood and implemented by all the actors of the national network (especially, the

\footnotetext{
${ }^{1}$ From then on, our conceptual framework focuses on a sport policy, understood as a 'vision statement' including the 'what?', 'why?' and 'who?' questions, and so is different from a strategy ('how') (Camy \& Robinson, 2007). The strategic, then operational planning appears subsequent and dependent on the sport policy (Robinson \& Minikin, 2011).
} 
clubs). From a sport management / policy point of view, the main purpose is to appreciate the ability of the actors to design a national sport policy and simultaneously, to create a stable and solid network, so as to better elaborate both, the conception and the implementation of this policy. The proposed conceptual framework moves away from a 'Top-Down' perspective and considers a NSF sport policy as a management tool which has to be co-constructed by several actors from both national and local level. Such an idea has been discussed by Fraser, et al (2006) and considered good practice when deriving strategic plans for organisations. However the unique nature of the structure of a NSF, as an actor network, may have led to difficulties in applying participatory strategies to the development of national sport policies for NSFs. (Kikulis, Slack \& Hinings, 1992; Bayle \& Robinson, 2007).

The first step was to identify how actors (policy designers), who have different positions and responsibilities throughout a NSF, who may have similar or opposite perceptions. Then it was necessary to understand how their different perceptions of the NSF sport policy which they design, could impact the content of this policy, as well as the collaboration between these actors needed to define this policy.

This paper presents the literature on national sport policies, as conceptualised in the case of a NSF. This is followed by the methodology used in the case of the FFR, aiming to collect and analyse the actors' perceptions. The results are then presented according to the proposed conceptual framework. Finally, implications for managers, limitations and perspectives of this study are discussed.

\section{CONCEPTUAL FOUNDATION}

\section{The concept of a sport policy and its application to a NSF.}

The concept of sport policy has seen an acceleration of academic interest over the past 20 years (Bergsgrad et al., 2007; Bloyce \& Smith, 2009, Houlihan, 2000; Hylton \& Bramham, 2008; Skille, 2008).

Previous research interested in sport policy(-ies) at national level can be categorised into three approaches: exploratory, descriptive or explanatory. Firstly, the literature provides an understanding of a sport policy as part of exploratory approaches. The authors (Bayle, 2007; Bayle \& Durand, 2004; Houlihan 2000; Houlihan \& White, 2002; King, 2009, Mezzaderi et al., 2015) were interested in the causes of any particular sport policy and the environment in which it operates. These works analyse a sport policy in terms of content, in relation to external impacts such as environment and history. Secondly, other authors focussed on the characterization of a given sport policy (descriptive approach). They describe a sport policy in terms of objectives, resources and results (Bravo \& Silva, 2014; Fahlén \& Stenling, 2015; Houlihan \& White, 2002; Skille, 2008, 2015; Winand, 2009). It is in this framework that Bergsgrad et al., (2007) then Hallman and Petry (2013) endeavoured to compare national sport policies. Thirdly, other research attempts to explain sport policy(-ies) (explanatory approach) using a managerial and/or sociological framework (Bernardeau Moreau, 2003, 2004; Bloyce \& Smith, 2010; Gasparini, 1997). These authors make the connection between 
governance, actors' games, power relationships and the sport policy that is in place. These reflections are regularly part of studies on organisational performance (Winand, 2009).

The common point of the research is to examine existing sport policy(-ies) and the impact of the environment on the development of the sport in question. Consequently, there has been a lack of attention towards the formulation of the policy itself and the factors that lead to its formulation. By understanding to what extent the perceptions of key stakeholders can impact the formulation of a sport policy, it may better inform the construction of a sport policy for NSFs that can be implemented at all levels of the organisation.

\section{Conceptualising the NSF sport policy: elements to be considered}

The starting point for conceptualising a national sport policy is to examine the main characteristics of a sport policy. Bloyce and Smith (2010, p.13) provide the following elements:

All policies can be viewed as involving the following overlapping and interrelated features: human action aimed at achieving certain objectives; [...] at resolving, or at least ameliorating, an identified 'problem'; and [...] at maintaining or modifying relationships within an existing organization, between different organizations, or a human figuration of some other kind.

These elements are relevant for a national sport policy as it integrates several actors, operating in different organisations at different levels. Given the characteristics of a NSF, the types of actors can be understood through three dimensions (Figure 1):

1. The network is constituted by organisations located in different geographical and hierarchical levels: headquarters or national level, affiliated associations, or regional level and clubs or the community level. (Bayle, 2007).

2. These organisations that are part of the network are composed of political actors, volunteers, sport technicians and administrative staff. All of them can be involved in and/or affected by the national sport policy (Houlihan, 2005, 2011)

3. Actors may take part at different levels during the formulation of the national sport policy (planning phase): some of them are involved in the conception of the sport policy, while others organise the conditions to achieve the objectives while others take responsibility for implementing these objectives through actions 'on the field'. Skille (2008) calls them the implementers.

Figure 1

Therefore, during the conception stage, it is important that the "designers" of the sport policy, are representative of this wide range of actors. Moreover, since the sport policy is a core element of a NSF; it may affect or be affected by external stakeholders. Even though we may not implement the policy it in terms of stakeholder management, Stakeholder Theory (Freeman, 1984; Donaldson \& Preston, 1995) enlightens us, as it distinguishes primary (Mason \& Slack, 2007) and secondary stakeholders (Clarkson, 1995). Freeman (1984) 
mentions important vs unimportant stakeholders of an organization. In appendix 1, a stakeholder classification is suggested based on a segmentation of internal / external and primary / secondary stakeholders. This stakeholder approach, classifies them (Parent \& Deephouse, 2007; Slack \& Parent, 2006).

The NSF sport policy also presents elements in terms of 'content' as underlined by researchers interested in exploratory approaches. Therefore it is a managerial dimension, because actors are dependant and have influence on each other. Consequently it may be beneficial to understand how the NSF sport policy is conceived, not from a methodological perspective ('step by step') but through an understanding of the dynamics of the relationships between the actors and their perceptions.

\section{Sport policy as a management tool}

The framework proposed by Hatchuel and Weil (1992), which has been tested on several occasions (Gilbert, 1997; David, 1998; Oiry, 2012), appears particularly robust and promising when attempting to apply a NSF sport policy as a management tool. The authors indicate that a management tool is the articulation of three heterogeneous elements: a formal substrate, a managerial philosophy and a simplified representation of the role of the actors (Hatchuel \& Weil, 1992) ${ }^{2}$ (Figure 2):

1. The formal substrate includes the documentation and so the content in which the tool is embodied. This documentation gives a reality to the tool and may include written documents, numerical data and measurable indicators.

2. The managerial philosophy behind the tool refers to the 'spirit' in which the tool is conceived; it describes the objectives allocated to the tool and how they might best be achieved according to the values of the organisation.

3. The simplified representation of the role of the actors reflects the representation of actors within the organisation, during the design of the tool. The actors (especially the designers) are necessarily led to hypothesise on how the users should behave in order to properly implement the NSF policies and thus is both effective and efficient, reflecting good governance.

Figure 2

The construction of a NSF sport policy, can then be considered a management tool that is applied to a national network (headquarters, affiliated associations and clubs). David (1996) then Moisdon (1997) define a management tool as the "formalisation of the organised activity". Consequently the NSF sport policy materialises, through the input and interactions of the three interdependent dimensions of the management tool as described above.

\footnotetext{
${ }^{2}$ It is worth mentioning that there is no hierarchical relation between these three elements.
} 
Two questions have been posed: 1 . How do the national and regional actors perceive the NSF sport policy while they are designing it? 2. What are the consequences for the NSF of these perceptions?

\section{CASE STUDY}

\section{The French Rugby Union}

The French Rugby Federation (FFR) is the governing body for rugby in France. It represents one of the most important NSFs in France as it claims to be supported by around 438000 members $^{3}$, deployed within 1,898 clubs, 34 regional and 102 departmental committees. Founded in 1919, the FFR was, three years later, recognised as promoting public interest by the Ministry of Sport, the French federations' and other relevant ministries. The goal of this non-profit organisation (association under French law in 1901) is, according to its statutes, "to stimulate and develop the practice of rugby in all its forms (traditional practice, seven...) in applying rules of the game settled by the International Rugby Board ${ }^{4}$, to guide and regulate rugby and to defend its interests" (translation of the Title 1, Article 1).

The FFR is above all, a member based sporting body, consisting of players, coaches, volunteers, its clubs and its different national teams, which play and perform at different levels. It has a complex governing structure, with an 'executive committee' (governing board), updated every two years and composed by 37 elected members and a steering committee with 16 political leaders. At the administrative level of the headquarters, the FFR is made up of six departments, including: the administration; sporting project department; sporting activities and legal department; financial department; and the human resources and territories' development department. In spite of its associative status, the FFR appears like a corporate company, with the management of more than 140 employees at the headquarters.

Two characteristics can be raised at the organisational level. First of all, the FFR has a pyramid shaped hierarchical structure operating from headquarters to the clubs through both regional and departmental committees. Secondly, the FFR has a working relationship with the Ministry of Sport, which is realised, on the human resources level, by the secondment of sport technical advisers (Article L. 131-12 of the French Code of Sport). These actors are, at the national level, members of the National Technical Direction, under the authority of a National Technical Director.

The French sport system relies on this 'co-management' between the NSFs and the State, which materialize through a convention of objectives (Bayle \& Durand, 2004). A Ministerial Directive of 2006 specifies that:

The State is responsible for the management of the sport policies in France. It delegates to the national federations the power to organise and promote the practice of their sporting disciplines and it supports them by means of conventions of objectives and the secondment of sport technicians (Instruction $n^{\circ} 06-169 \mathrm{JS}$ of the $11^{\text {th }}$ of October, 2006).

\footnotetext{
${ }^{3}$ Data from April, 2016. Rugby is the seventh sport for the number of licensees in France.

${ }^{4}$ Now "World Rugby".
} 
Recently, rugby has known an accelerated development in France, with a strong increase in the number of members, especially since 2007 following the organisation of the Rugby World Cup. Consequently, this sport has benefited from an increase in stadium attendances and media coverage of its national activities. This quantitative development has been followed by the professionalization of its activities, individuals, structures and processes (Nagel et al., 2015). These dimensions - entrepreneurial, "co-management" with the State and professionalization - have been taken into account, during the course of this investigation.

The sudden increase or 'peak of development' is reflected in the preface of the French Rugby White Paper, written in 2010, in which the President of the FFR announced: 'Rugby has reached a stage of its development which undeniably constitutes a new step and we should stop an instant so as to have the means to pursue our progression'.

In line with this reflection the FFR has changed its organisational and management structure as illustrated by the arrival of a new National Technical Director in October 2014. Finally the FFR appears to want to establish more appropriate relationships with its regional committees, through the implementation of a financing model that will provide funding on the basis of strategic regional projects, rather than on the basis of numerical data (number of clubs, teams and members in the region), as has been the case in the past.

Accordingly, these organisational and structural pressures have pushed the FFR to commit to a reflection process around its sport policy.

\section{Data collection}

A qualitative design was chosen, which as Wacheux (1996, p.15) describes: 'qualitative research is firstly about understanding the Why and the How of some events in concrete situations'. Qualitative techniques are useful for exploring and describing elements of a problem in depth and detail, by examining situations with characteristics that may not be easily represented in numerical format (Leedy \& Ormrod, 2010; Patton, 2012). According to Rubin and Rubin (2005), the goals of qualitative data analysis are 'to reflect the complexity of human interactions by portraying it in the words of the interviewees and through actual events and to make that complexity understandable to others' (p. 202). More than exploring and describing, our aim was to understand and analyse the actors' perceptions of a NSF sport policy, using the case of the FFR.

A case study approach was conducted to comprehend the phenomenon as a whole, but also to detect dynamics (even in the short-term) that a survey could not identify (Yin, 2003). A case study approach is recommended when some evolution within the organisation occurs and furthermore when exploring a phenomenon not covered so far (Yin, 2003). This case study is considered as unique (Stake, 1995); the headquarters and the regional organisations that make up the FFR are understood to include a network organisation / an actor network. A series of semi-structured interviews were conducted with both regional and national actors (Table 1). The aim of semi-structured interviews was to collect the viewpoints, thoughts and observations of some persons who have a special knowledge about a subject, a special status and/or information about which the researcher cannot have any access by other means. Semi- 
structured interviewing enabled the researcher to follow leads, ask additional probing questions, and let the interview take its course (Pomeranz, Needham, \& Kruger, 2015). This type of interview required the use of a schedule, which is a collection of questions and topics that the researcher wanted to cover (Bernard, 2006). Nevertheless, this schedule was intended more as a guide than an explicit set of questions that each respondent must answer (Bernard, 2006). Interviews ended when no new information was forthcoming (i.e. a saturation point was reached). The schedule was structured in order to question actors on each dimension of the conceptual framework (the NSF sport policy framework): 1) an introductory part, to explain the study and the aim of the interview, 2) the definition of the FFR sport policy, 3) the perceptions of the actors of what the FFR sport policy should be, 4) the actors impacted and their roles, 5) the perceived benefits and 6) the conclusion, with the factors of success or failure for this process.

A total of 45 interviews were conducted from May 2014 to February 2015. This is a relatively large number of participants for a qualitative study involving semi-structured interviews (and other data sources), and none of the individuals declined after having been asked to participate (Bernard, 2006; Patton, 2002). Interviews lasted between 29 and 95 minutes, averaging approximately 60 minutes.

Respondents were selected because of their influence and the important roles they may play in relation to the formulation and/or implementation of the FFR sport policy; this selection was made in collaboration with national actors behind this research (1 board member, 1 sport technician and 2 administrative managers). ${ }^{5}$

Interviews were conducted with both national and regional actors with various statutes (16 board members, 16 sport technicians and 13 administrative managers), given that the objective was to have a balance between these different 'types' of actors and a geographical representation including representative actors from the north/south and east/west of France, (Appendix 2).

It is worth noting that some board members of the FFR also simultaneously held a senior position with a regional association. The same situation also occurred with the sport technicians (especially those who depend on the Ministry of Sport), with some of them undertaking activities both at national and regional level. Sport politicians and technicians who act only at the regional level, were also interviewed. The different status and geographical location of the actors addressed the elements of the conceptual framework from the perspective of national, regional and club actors who are part of a single national organisation as reflected by the FFR.

\footnotetext{
${ }^{5}$ To make the link with the stakeholder approach, we opted for both primary and internal stakeholders of the federation sport policy (cf. page 5); they must take into account the potential interests of both secondary and external stakeholders of this policy (Slack \& Parent, 2006).
} 


\section{Data analysis}

A thematic content analysis was performed, by transcribing each interview and by holding a research book. Thematic analysis is used in qualitative research and focuses on examining themes that become evident within sets of data; an appropriate method to highlight actors' viewpoints and representations at a given time. Thematic analysis goes beyond simply counting phrases or words in a text and moves on to identify implicit and explicit ideas within the data (Guest, MacQueen \& Namey, 2012). Coding is the primary process for developing themes within the raw data by recognizing important moments in the data and encoding it prior to interpretation (Boyatzis, 1998).

A first level of analysis and coding was made using a deductive approach with three 'macrocodes' from the conceptual framework: a formal substrate, a managerial philosophy and a simplified representation of the role of the actors. Following this meta-coding (Miles \& Huberman, 1994), a categorization of data was used, according to the frequencies and redundancies of answers (Guest, MacQueen \& Namey, 2012).

A total of nine subcategories emerged from the interviews and the different log notes. A horizontal approach was favoured (searching the agreements and controversies for each subcategory). For example, from one interview to the other, this involved identifying the recurrent themes and opinions. Then, a vertical approach was followed to determine agreements and controversies for the types of actors.

These main subcategories were developed and presented in the following results section and were illustrated, in particular, by selected verbatim quotes from respondents.

\section{RESULTS}

\section{The formal substrate}

A NSF sport policy suggests some formal elements. When the actors addressed the written documentation, or the 'formal substrate' of the FFR sport policy, it appears that they have different perceptions in terms of content. Figure 3 summarises actors' perceptions about the "formal substrate" dimension.

Figure 3

The first component highlighted was the representation of the FFR policy by actors. A convergent dimension was that of a 'project'. Actors, when attempting to define the FFR policy, saw it as a project, with objectives and a time scale. Consequently, the characterization of this project differs depending on each actor, and the context in which they operate. It was interesting to note that, for a political actor (e.g. a regional committee's President), it is about 'the main priorities that the federation is giving itself for the next four years, for a mandate, even more' [P15]. Alternatively, for a sport technician, it is above all 'a shared sports project between the Federation and the DTN [National Technical Direction]. These are shared 
objectives' [S1]. Finally, a national administrative manager defined it as 'a proposed working organisation' [A13].

Beyond this general definition, actors distinguish themselves by the way they present the content and priorities of the FFR sport policy. Three different representations emerge: three areas ('development', 'training' and 'high-level'), types of practices to be developed ('Rugby with 5 players' - called 'touch rugby' in the UK -, 'Rugby Sevens' and 'Traditional Rugby'), and between two 'worlds', 'grassroots sport' and 'professional/elite sport'. In terms of priorities, all actors highlighted the importance of the ' $X V$ de France' (the national men's rugby team) results. However, as a respondent mentioned: 'We have some people who think that the most important thing, today, is to develop the Sevens part for the Olympic Games' [S6].

Occasionally, the perceptions of national and regional actors converged to form a consistent view over aspects such as the number of licensees. For example 'if we have a decrease of our numbers, it is difficult' [S14]; 'With 100,000 licensees, the sponsors will leave' [A1]. Actors generally agreed the need to stabilise the membership as a core theme that will enable other aspects of the sport policy to become achievable such as competitions, club management and development activities.

The analysis of the semi-structured interviews with regional actors shows a disparity between regional committees in the south of France, where rugby is culturally more developed, and the northern part of the country, where the room for growth appears to be more important. Respondents noted a difference in priority for different parts of the country: 'Us, for example, in our region, we are not in an expansion policy, but in a qualitative development: better access to practice, public diversification, achievement of non-sporting goals, etc.' [P9].

The last component, falls within two levels of perceptions of the FFR policy. Some actors judge that there is no FFR sport policy, because 'I do not see any framework for action, with specific goals', 'I do not see any common thread and a well-defined and clear strategy in terms of sport policy' [P10]. Others consider that, because there are some sport projects clearly identified, there is a sport policy that consists of the sum of these sport projects.

This difference in the perception of an effective content can be explained by the fact that the perceived content is 'biased, with many actions developed at the same time for specific areas such as rugby development. Actors therefore, expressed difficulties in understanding the priorities of the FFR overall.

\section{The managerial philosophy}

When the actors were asked to articulate what a well-defined NSF sport policy can provide, some key elements were highlighted. Figure 4 sums up these actors' perceptions.

Figure 4 
Firstly, the sport policy may give more clarity on what the FFR wishes (where it wants to go), particularly concerning its sporting objectives. Consistent with some perceptions raised in the formal substrate dimension, the observation is that 'there are things that occur, but $[\ldots]$ it is difficult to see the purpose' [P15]. Furthermore, respondents agreed on a lack of clarity and so effectiveness: 'maybe we lack a unity of vision and currently [...] we are doing a little bit of everything and so we are missing power in what we should do' [S6]. A board member went further, speaking about motivational factors: 'I think we should re-motivate the overall system, on sporting goals' [P5]. The sport technician added the opportunity to evaluate these objectives: 'it is important to have measurable objectives' [S5].

The second aspect raised by actors is to improve the functioning of the internal organisation (headquarters management), which is one of the organizational performance dimensions identified by Winand et al. (2010). From the administrative actor's point of view, the development of a sport policy may be the opportunity for an evolution of the organisation. At the level of the administrative managers, better teamwork between sporting and administrative activities / actions should be sought: 'I sincerely think that having somebody who makes the connection between the "sporting" and administrative professions [...], it could be good' [A3]. Moreover, some sport technicians see the opportunity to know more about the contribution of each other to a project, and so to give sense to their action. A DTN actor insists on this: 'having a clear sport policy, well-defined, in which people exactly know what they have to do, provides a multiplier effect on energy' [S16].

Thirdly, the NSF sport policy represents, for the actors, an opportunity to improve the functioning of the organisation, between the headquarters and the decentralised committees. The analysis of the interviews emphasises a wish from the regional actors to have more exchange and relationships. Two quotes illustrate this: 'It could be good that there is a discussion: for example, that periodically, they (the DTN) come to the committees and tell us what they expect from us' [P14] and 'I think that a relational structure between the headquarters and its regional committees is lacking, extending further between the regional and departmental committees' [S7].

The other dimension highlighted is the feeling of collective belonging that the sport policy enables, and which is also meant as a condition of success: 'the main idea is to have a framed project that associates all the stakeholders' [S14].

From a general point of view, what emerges in terms of a managerial philosophy is a convergence of the opportunity to develop headquarters action, with a positive impact for the network.

\section{The roles of the actors and their relations}

As indicated above, the question of the roles and responsibilities of each actor, as well as the relationships, is essential. Figure 5 provides an overview on actors' perceptions about the role of the actors and their relations. 
First of all, respondents of the national level relied on both relational and organisational dynamics, such as: 'we do not have any exchange between us, this is too compartmentalised' [P14]. Perceptions converged towards a need for more shared information and working methods that are more "standardised': 'Now, the developmental factors, especially for the headquarters, will be to get even more coordination and lateral development' [A1]; 'A project can be accepted if and only if it is shared by everybody. We will agree on it only if we will appropriate it' [S7].

In the same vein, some sport technicians indicated a lack of awareness about other's activity. For example: 'for me, there is [...] a lack of information. To know who does what? What are you exactly working on? Why are you doing this?' [S5]. These perceptions on the interface between actors must be taken into account during the conception process of the sport policy as they appear as conditions of success as much as improvement of work efficiency, with the idea of getting people onto the same page. It may be appropriate to emphasise the need to communicate more effectively so that a national objective can be applied more effectively at the regional and club level (Skille, 2008, 2015).

The identification of key actors constitutes an essential point in this study and showed agreement; however, a controversy was the roles allocated to each. It appears that several actors with various positions (as indicated in Figure 1) have a role in the design process of the sport policy. First, the role of the executive committee, in particular the Chairman, appeared to be important. Among these federation board members, some of them also hold a position such as the presidency of a regional committee, which will confer them an additional role in the implementation, the follow-up 'on the field' of the sport policy. For example, 'We cannot deny ourselves the contribution of the Presidents of the Committees, because they are the ones who daily implement the actions, the policy' [P15]. This dual role of President of a regional body as well as sitting on the federation board may be normal as the board is elected from regional officers through club officers (the latter 'give' their voices to the first). Nevertheless, this may be problematic as a confused role may lead to greater likelihood for individuals to exert their personal views over their constituents' views. Concerning the sport technicians, an important role is given to the DTN and its regional sport managers, as a proactive force. The perceptions about these key actors identified and their roles reveal some issues in terms of power and question the persuasiveness of the sport technicians, influencing the choices made towards a sport policy.

There appears to be a divergence of opinion about the relationship between the headquarters and regional committees. Some of the respondents believe in centralisation, while others prefer decentralisation. Paradoxically, regional actors appeared to be waiting for a sport policy coming from the headquarters: 'It is up to the headquarters to prioritize its actions, define which ones the committees must carry out. Define the content' [P10]. Whereas the national actors are in favour of more proposals emanating from the regional committees: 'This is for them to know what is their degree of involvement, in the development and elite of their sport, inside their territory' [P16]. From this, it seems that this is up to the regional committees to define their own sport policy, in accordance with their specific features. 
Consequently, actors place more importance on the external 'superior' or 'inferior' issues over their own responsibilities when contributing to the development of a NSF sport policy. This illustrates the hierarchical perception of sport structures that leads to the situation described.

\section{DISCUSSION}

\section{Summary of findings}

This research highlights both agreement and conflict between the actors. Overall, they appear to focus on the 'managerial philosophy' dimension, in identifying elements perceived as defects that the NSF sport policy can improve, such as the clarification of objectives, the internal functioning of the headquarters and the relations between the latter and the decentralised committees. It might be argued that this dimension is easier to manage and better understood by the actors who contribute to the formulation of a national sport policy as they tackle strategic issues based on the organisational variables in their environment that they can control (Robinson et al., 2007). The two other dimensions - formal substrate and visions about the roles and relations - appear more controversial. Indeed, some actors expressed different views about the future of the sport and the influence of each actor within this collective reflection. This might indicate a less consistent and clear perception of what the purpose of their sport is (Bayle et al., 2007).

Through their perceptions, respondents suggest the importance of a number of contexts, such as:

- political (referring to the governance),

- economic (they raised the question of the means),

- sporting (influence of the last results),

- managerial, i.e. the impact of the federation organisation on the NSF sport policy (in particular the functioning of the headquarters and the relations with the committees).

The issues raised are firstly strategic: aiming to define choices in terms of 'prospects/perspectives' of development of rugby and its governing organisation. Once these choices are made, they have an impact on the future of the sport. Moreover, the conception of the NSF sport policy may be accepted as the basis for the establishment of a strategic or operational plan, for the planned development of rugby practice. The perception of the regional committees, suggests that the sport policy is there to provide an organised framework for actions, throughout the country. The main challenge is to implement a homogeneity throughout the country, a 'governing principle', so as to ensure that the NSF sport policy can be applied in practice and will be adaptable everywhere (Donaldson, Leggett, \& Finch, 2012). This enables a 'one size fits all' approach allowing a degree of regional freedom. It falls on 
management to inform the governing board if they have the capabilities and resources at all levels of the organisation to implement each of the policy objectives.

This study also highlights the need to move away from a 'Top-Down' approach to strategy development as this may lead to a potential lack of consistency with regional contexts. However, it also suggests that a Down-Top approach should also be avoided as regional actors are not used to defining their own sport policy. Finally, it is also necessary to consider the sport policy as a management tool as this enables the importance of the perceptions of several actors in the formalisation of the sport policy to be recognised. The need to take into account all stakeholders from the national to the local level is essential since each component part of the actor network operates in a different environment, which implies the need to adapt a national framework to a number of contexts.

The research suggests that actors, at all levels, do not need to apply mechanically a federation sport policy objectives. By understanding the local context and environment, regional and local actors have the possibility to adapt the strategy appropriately in line with their position, their expectations and their vision about the role of a NSF sport policy. Capturing the perceptions of the key stakeholders regarding a NSF sport policy appears a prerequisite to understanding how the actors will engage in the design process of the NSF sport policy and the shape that the latter will take. This is made possible by following a matrix which also takes into account both the content and the managerial and organisational dimensions related to this policy - the management tool. It is important for managers to have in mind that a better managerial practice does not necessarily require the same performance criteria in every situation that it is applied. This research suggests that, focusing on the conditions facilitating a better managerial performance in the long term and in a variety of conditions will lead to better national outcomes.

\section{Limitations and perspectives}

Findings presented here have the limit of being 'static' as they are only at a given moment, at the beginning of the conception process. In order to understand and master the 'trajectory' of the NSF sport policy, but also to focus on the dynamics of the actors who build it together, the Actor-Network Theory (ANT) may need to be used in further research (Callon, 1986; Akrich, Callon \& Latour, 2006). Dreveton (2011) then Oiry (2012) rely on ANT to appreciate the design process of a management tool after having considered the latter as a social construct (Grimand, 2006). ANT, through the notion of 'translation', gives an explanation about the progress - or not - of the co-construction process and appears as a methodology of intervention. Using this framework, further research can focus on understanding and analysing if the final content of the NSF sport policy that can be anticipated corresponds to what actors have planned and how each actor manages - or does not - to 'incorporate' its translation into the tool and so to make it evolve.

As a consequence, a second series of interviews will be necessary so as to understand the operational progress of the project and the constitution and stabilisation of the network, that is to what extent actors are interested, recruited and mobilised after the formulation of the 
problem (problematization). The Actor-Network Theory will enable reflection of the constitution of the network through its four phases.

Another additional area of work is the application of our approach in other sport organisations. In particular, it would be interesting to conduct a similar research in a sport organisation with a different structure in order to comprehend the impact of the latter on the operational formalisation of the sport policy. This would enable to enrich our analysis and maybe identify other directions and interpretations that are absent here so as to build a more general framework. 


\section{References}

Akrich, M., Callon, M., \& Latour, B. (2006). Sociologie de la traduction : Textes fondateurs [Sociology of translation: Founding texts]. Paris: Presses des Mines de Paris.

Barney, J. B. (1991). Firm resources and sustained competitive advantage. Journal of Management, 17, 99-120.

Bayle, E. (2007). Essai de définition du management des organisations sportives: Objet, champ, niveaux d'analyse et spécificités des pratiques managériales [Attempt at defining sport organisation management: Subject, field, levels of analysis and specificities of managerial practices]. Staps, 75, 59-81.

Bayle, E., Duncan, J., Chappelet, J. L., \& Kartakoullis, N. (2007). Managing strategically. In J. Camy \& L. Robinson (Eds), Managing olympic sport organisations (pp. 61-106). Champaign, IL: Human Kinetics.

Bayle, E., \& Durand, C. (2004). Vingt ans de relations entre le mouvement sportif et l'Etat : D'une collaboration ambivalente vers une régulation managériale ? [Twenty years of relations between the sport movement and the State: From an ambivalent relationship to a managerial regulation?] Politiques et Management Public, 22(2), 125-144.

Bayle, E., \& Robinson, L. (2007). A framework for understanding the performance of national governing bodies of sport. European Sport Management Quarterly, 7(3), 249-268.

Bergsgrad, N.A., Houlihan, B., Mangset, P., Nedland, S.I., \& Rommetvedt, H. (2007). Sport policy: A comparative analysis of stability and change. Oxford: Butterwoth-Heinemann.

Bernard, H. (2006). Research methods in anthropology. Lanham, MD: AltaMira.

Bernardeau Moreau, D. (2003). La professionnalisation dans les organisations associatives : Le cas des dirigeants bénévoles de la Fédération Française d'Equitation [The professionalisation in non-profit organisations: The case of the French Equestrian Federation volunteer managers]. Gérer et Comprendre, 73, 55-77.

Bernardeau Moreau, D. (2004). Sociologie des fédérations sportives [Sociology of sport federations]. Paris: L'Harmattan.

Bloyce, D., \& Smith, A. (2010). Sport policy and development: An introduction. London: Routledge.

Boyatzis, R. (1998). Transforming qualitative information: Thematic analysis and code development. Thousand Oaks, CA: Sage

Bravo, G., \& Silva, J. (2014). Sport policy in Chile. International Journal of Sport Policy and Politics, 6(1), 129-142.

Callon, M. (1986). Éléments pour une sociologie de la traduction : La domestication des coquilles Saint-Jacques et des marins-pêcheurs dans la baie de Saint-Brieuc [Elements for a sociology of translation: Domestication of scallops and fishermen in Saint-Brieuc bay]. L'Année Sociologique, 36, 169-208.

Camy, J., \& Robinson, L. (Eds) (2007). Managing olympic sport organisations. Champaign, IL: Human Kinetics.

Clarkson, M. B. E. (1995). A Stakeholder Frameword for Analyzing and Evaluating Corporate Social Performance», Academy of Management Review, 20(1), 92-117.

David, A. (1998). Outil de gestion et dynamique du changement [Management tool and dynamic of change]. Revue Française de Gestion, 120, 44-59.Donaldson, A., Leggett, S., \& Finch, C. (2012). Sports policy development and implementation in context: Researching and understanding the perceptions of community end-users. International Review for the Sociology of Sport, 47(6), 743-760.

Donaldson, T., \& Preston, L. E. (1995). The Stakeholder Theory of the Corporation: Concepts, Evidence and Implications. Academy of Management Review, 20(1), 65-91. 
Dreveton, B. (2011). Construire un outil de contrôle au sein des organisations publiques : Une opportunité au développement d'un nouveau mode d'action [Build a control tool within public organisations: An opportunity for the development of a new mode of action]. Management International, 15(4), 11-24.

Fahlén, J., \& Stenling, C. (2015). Sport policy in Sweden. International Journal of Sport Policy and Politics, Published online, doi: 10.1080/19406940.2015.1063530

Fédération Française de Rugby (FFR) (2012). Le livre blanc du rugby français : Construire ensemble notre avenir [White paper of French rugby: Building together our future]. Marcoussis, France: http://www.ffr.fr/Livre_Blanc/index.html

Finlay, P. (2000). Strategic Management: An Introduction to Business and Corporate Strategy. Prentice Hall: Harlow.

Fraser, E.D., Dougill, A.J., Mabee, W.E., Reed, M., \& McAlpine, P. (2006). Bottom up and top down: Analysis of participatory processes for sustainability indicator identification as a pathway to community empowerment and sustainable environmental management. Journal of environmental management, 78(2), 114-127.

Freeman, R. E. (1984). Strategic Management: A Stakeholders Approach. Boston: Pitman. Friedman M. T., Mason D. S. (2004). A Stakeholder Approach to Understanding Economic Development Decision Making: Public Subsidies for Professional Sport Facilities. Economic Development Quarterly, 18, 236-254

Friedman, M.T., Parent, M.M., \& Mason, D.S. (2004). Building a framework for issues management in sport through stakeholder theory. European Sport Management Quaterly, 4, 170-190.

Gasparini, W. (1997). La construction sociale de l'organisation sportive : Champ et engagement associatif [The social construction of the sport organisation: Field and associative involvment]. Revue STAPS, 43, 51-59.

Gavard-Perret M.-L., Gotteland D., Haon, C. \& Jolibert, A. (2008). Méthodologie de la recherché : Réussir son mémoire ou sa thèse en sciences de gestion [Research methodology: Succeeding in dissertation or thesis in management sciences]. Pearson Education, Paris.

Gilbert, P. (1997). L'instrumentation de gestion [Management instrumentation]. Paris: Economica.

Gregory, G.H., Chapman, C. (2012). Differentiated instructional strategies: One size doesn't fit all. Thousand Oaks, CA: Corwin Press.

Grimand, A. (2006). L'appropriation des outils de gestion: Vers de nouvelles perspectives théoriques? [The appropriation of management tools: Towards new theoretical perspectives?] Saint-Etienne, France: Presses Universitaires de Saint-Etienne.

Guest, G.S., MacQueen, K. M. \& Namey, E.E. (2012). Applied Thematic Analysis. Thousand Oaks, CA: Sage.

Hallman, K., \& Petry, K. (Eds) (2013). Comparative sport development: Systems, participation and public policy. Heidelberg, Germany: Springer.

Hatchuel, A., \& Weil, B. (1992). L'expert et le système [The expert and the system]. Paris: Economica.

Houlihan (2000). Politics and sport. In Dunning, E and Coakley, J. (Eds), Handbook of Sport and Sociology, Sage, pp. 213-227.

Houlihan, B. (2005). Public sector sport: Policy developing a framework for analysis. International Review for the Sociology of Sport, 40(2), 163-185.

Houlihan, B. (2011). Defining Sports Development. Sportdevelopment.info: http://www.sportdevelopment.info/index.php/rgsd/265-definition

Houlihan, B., \& White, A. (2002). The politics of sport development: Development of sport or development through sport? London: Routledge. 
Hylton, K., \& Bramham, P. (Eds.) (2008). Sports development: Policy, process and practice. London: Routledge.

Kikulis, L.M., Slack, T., \& Hinings, B. (1992). Institutionally specific design archetypes: A framework for understanding change in national sport organizations. International review for the sociology of sport, 27(4), 343-368.

King, C. (2009). Sport policy and governance: Local perspectives. Oxford: ButterworthHeinemann.

Leedy, J., \& Ormrod, P. (2010). Practical research: Planning and design. Upper Saddle River, NJ: Prentice Hall.

Mason, D.S., \& Slack, T. (1997). Appropriate opportunism or bad business practice? Stakeholder theory, ethics, and the franchise relocation issue. Marquette Sports Law Journal, 7(2), 399-426

Mezzadri, F., Moraes e Silva, M., Mello Figuêroa, K., \& Starepravo, F. (2015). Sport policies in Brazil. International Journal of Sport Policy and Politics, 7(4), 655-666.

Miles, M.B, \& Humberman, A.M. (1994). Qualitative data analysis: An expanded sourcebook. Thousand Oaks, CA: Sage Publications.

Moisdon, J-C. (1997). Du mode d'existence des outils de gestion [Management tools' lifestyle]. Paris: Seli Arslan.

Nagel S., Schlesinger T., Bayle E., Giauque D. (2015). Professionalisation of sport federations: A multi-level framework for analysing forms, causes and consequences. European Sport Management Quarterly, 15(4), 407-433.

Oiry, E. (2012). La conception des instrumentations de gestion RH : L'apport du concept de rapport de prescription [The design process of a HR management tool: The contribution of the concept of prescriptive relation]. @ GRH, 5, 11-44.

Parent, M. M., \& Deephouse, D. L. (2007). A Case Study of Stakeholder Identification and Prioritization by Managers. Journal of Business Ethics, 75(1), 1-23.

Patton, M. (2002). Qualitative research and evaluation methods. Thousand Oaks, CA: Sage.

Pomeranz, E., Needham, M., \& Kruger, L. (2015). Perceptions of stakeholders regarding wilderness and best management practices in an Alaska recreation area. Managing Sport and Leisure, 20(1), 36-55.

Putler, D.S., \& Wolfe, R. (1999). Perceptions of intercollegiate athletic programs: Priorities and tradeoffs. Sociology of Sport Journal, 16, 301-325.

Robinson, L., Camps Povill, A., Henry, I., Vandeputte, L., \& Clark, M. (2007). Organising an Olympic sport organisation. In J. Camy \& L. Robinson (Eds), Managing olympic sport organisations (pp. 1-60). Champaign, IL: Human Kinetics.

Robinson, L., \& Minikin, B. (2011). Developing strategic capacity in Olympic sport organisations. Sport, Business and Management: An International Journal, 1(3), 219-233.

Rose, R. (1969). Policy making in Britain: A reader in government. New York: Free Press.

Rubin, H., \& Rubin, I. (2005). Qualitative interviewing: The art of hearing data. Thousand Oaks, CA: Sage.

Skille, E. (2008) Understanding sport clubs as sport policy implementers: A theoretical framework for the analysis of the implementation of central sport policy through local and voluntary sport organizations. International Review for the Sociology of Sport, 43, 181-200.

Skille, E. (2015). Community and sport in Norway: Between state sport policy and local sport clubs. International Journal of Sport Policy and Politics, 7(4), 505-518.

Slack, T., \& Parent, M.M. (2006). Understanding Sport Organizations. Leeds: Human Kinetics Europe.

Stake, R. E. (1995). The art of case study research. Thousand Oaks, CA: Sage.

Winand, M. (2009). Déterminants de la performance organisationnelle des fédérations sportives : Une analyse comparée des ligues sportives de la Communauté française de 
Belgique [Determinants of organisational performance of sport federations: A comparative analysis of sport governing bodies from the French speaking Community of Belgium]. $\mathrm{PhD}$ in motor sciences, Université catholique de Louvain, Louvain-la-Neuve, Belgium.

Winand, M., Zintz, T., Bayle, E., \& Robinson, L. (2010). Organizational performance of Olympic sport governing bodies: dealing with measurement and priorities. Managing Leisure, 15(4), 279-307.

Wacheux, F. (1996). Méthodes qualitatives et recherche en gestion [Qualitative methods and research in management]. Paris: Economica.

Yin, R.K. (2003). Case study research: Design and methods. Thousand Oaks, CA: Sage. 


\section{Appendices}

Appendix 1. The design process of a NSF sport policy: a stakeholder classification based on a segmentation between internal / external and primary / secondary stakeholders.

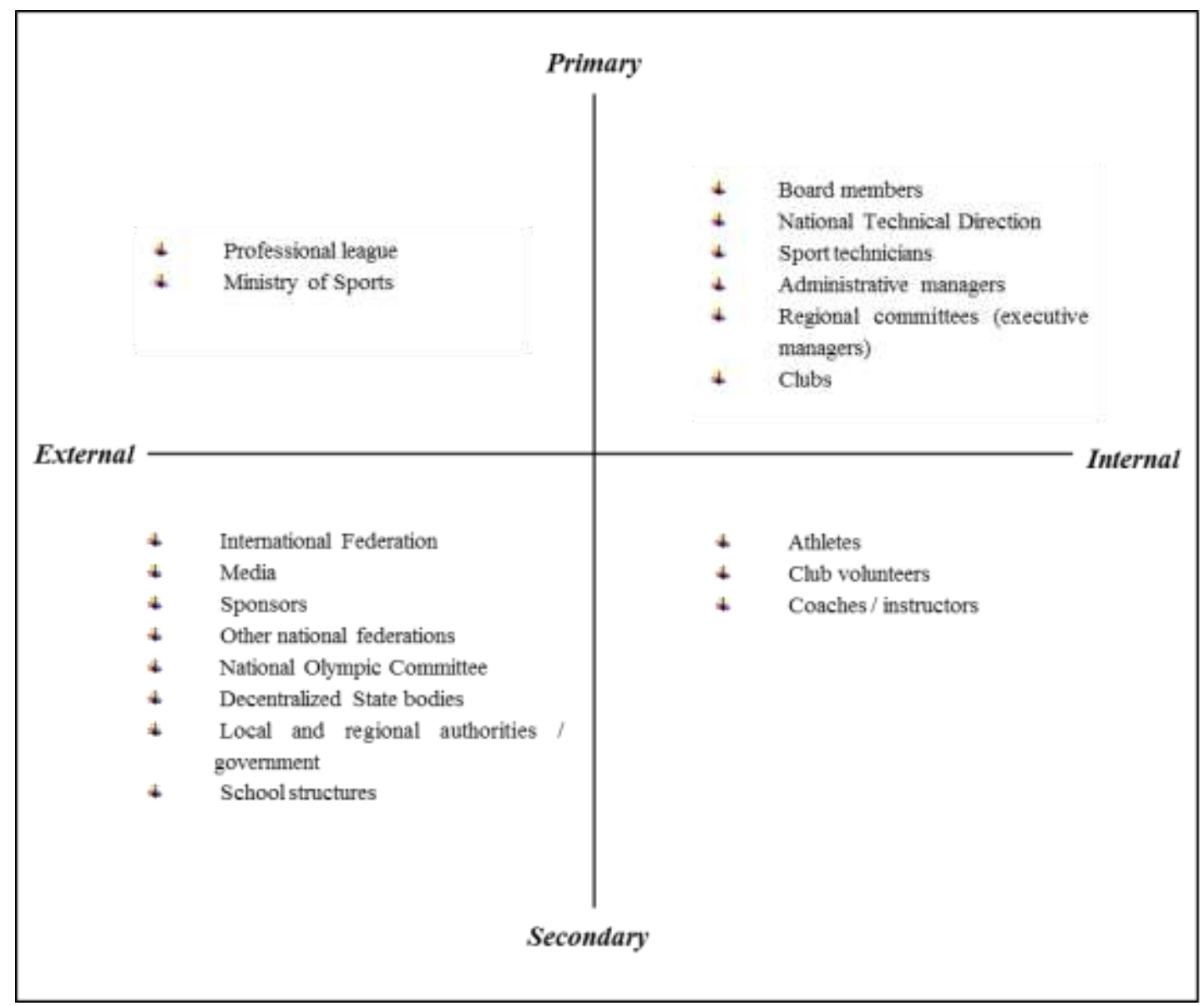


Appendix 2. Interview list of stakeholder participants.

\begin{tabular}{|c|c|c|}
\hline $\begin{array}{c}\text { Pseudonym - } \\
\text { Respondent code } \\
\text { number }\end{array}$ & Interview length & Typology - Role \\
\hline P1 & 1 hour 8 minutes & Board member \\
\hline $\mathbf{P 2}$ & 40 minutes & $\begin{array}{l}\text { Board member \& President of a Regional } \\
\text { Committee }\end{array}$ \\
\hline $\mathbf{P 3}$ & 41 minutes & Board member \\
\hline $\mathbf{P 4}$ & 1 hour & Board member \\
\hline P5 & 56 minutes & Board member \\
\hline P6 & 36 minutes & Board member \\
\hline P7 & 54 minutes & Board member \\
\hline P8 & 1 hour 32 minutes & $\begin{array}{l}\text { Board member \& President of a Regional } \\
\text { Committee }\end{array}$ \\
\hline P9 & 1 hour 8 minutes & $\begin{array}{l}\text { Board member \& President of a Regional } \\
\text { Committee }\end{array}$ \\
\hline P10 & 45 minutes & $\begin{array}{l}\text { Board member \& President of a Regional } \\
\text { Committee }\end{array}$ \\
\hline P11 & 52 minutes & President of a Regional Committee \\
\hline P12 & 29 minutes & $\begin{array}{l}\text { Board member \& President of a Regional } \\
\text { Committee }\end{array}$ \\
\hline $\mathbf{P 1 3}$ & $\begin{array}{l}1 \text { hour } 12 \text { minutes (in pairs } \\
\text { with S12) }\end{array}$ & Vice-president of a Regional Committee \\
\hline P14 & 1 hour 1 minute & President of a Regional Committee \\
\hline P15 & 1 hour 8 minutes & President of a Regional Committee \\
\hline P16 & 42 minutes & Board member \\
\hline S1 & 45 minutes & Regional and national sport technician \\
\hline S2 & 1 hour 19 minutes & Regional and national sport technician \\
\hline S3 & 1 hour 23 minutes & Regional and national sport technician \\
\hline S4 & 1 hour 25 minutes & Regional and national sport technician \\
\hline S5 & 1 hour 7 minutes & National sport technician \\
\hline S6 & 1 hour 5 minutes & National sport technician \\
\hline S7 & 1 hour 20 minutes & National sport technician \\
\hline S8 & 1 hour 1 minute & National sport technician \\
\hline S9 & 56 minutes & National sport technician \\
\hline S10 & 58 minutes & Regional and national sport technician \\
\hline S11 & 1 hour 20 minutes & Regional sport technician \\
\hline S12 & $\begin{array}{l}1 \text { hour } 12 \text { minutes (in pairs } \\
\text { with } P 13 \text { ) }\end{array}$ & Regional sport technician \\
\hline S13 & 39 minutes & Regional sport technician \\
\hline S14 & 53 minutes & National sport technician \\
\hline S15 & 55 minutes & National sport technician \\
\hline S16 & 53 minutes & National sport technician \\
\hline A1 & 58 minutes & Administrative manager \\
\hline $\mathbf{A 2}$ & 1 hour 2 minutes & Administrative manager \\
\hline $\mathbf{A 3}$ & 1 hour 16 minutes & Administrative manager \\
\hline A4 & 49 minutes & Administrative manager \\
\hline A5 & 1 hour 10 minutes & Administrative manager \\
\hline A6 & 1 hour 11 minutes & Administrative manager \\
\hline A7 & 59 minutes & Administrative assistant - Sport Dpt \\
\hline A8 & 1 hour 45 minutes & Administrative assistant - Sport Dpt \\
\hline A9 & 56 minutes & Administrative assistant - Sport Dpt \\
\hline A10 & 1 hour 8 minutes & Administrative manager \\
\hline A11 & 54 minutes & Administrative manager \\
\hline A12 & 56 minutes & Administrative manager \\
\hline $\mathbf{A 1 3}$ & 1 hour 14 minutes & Administrative manager \\
\hline
\end{tabular}




\section{Figures}

Figure 1. Illustrates the NSF sport policy: several actors operating in a network.

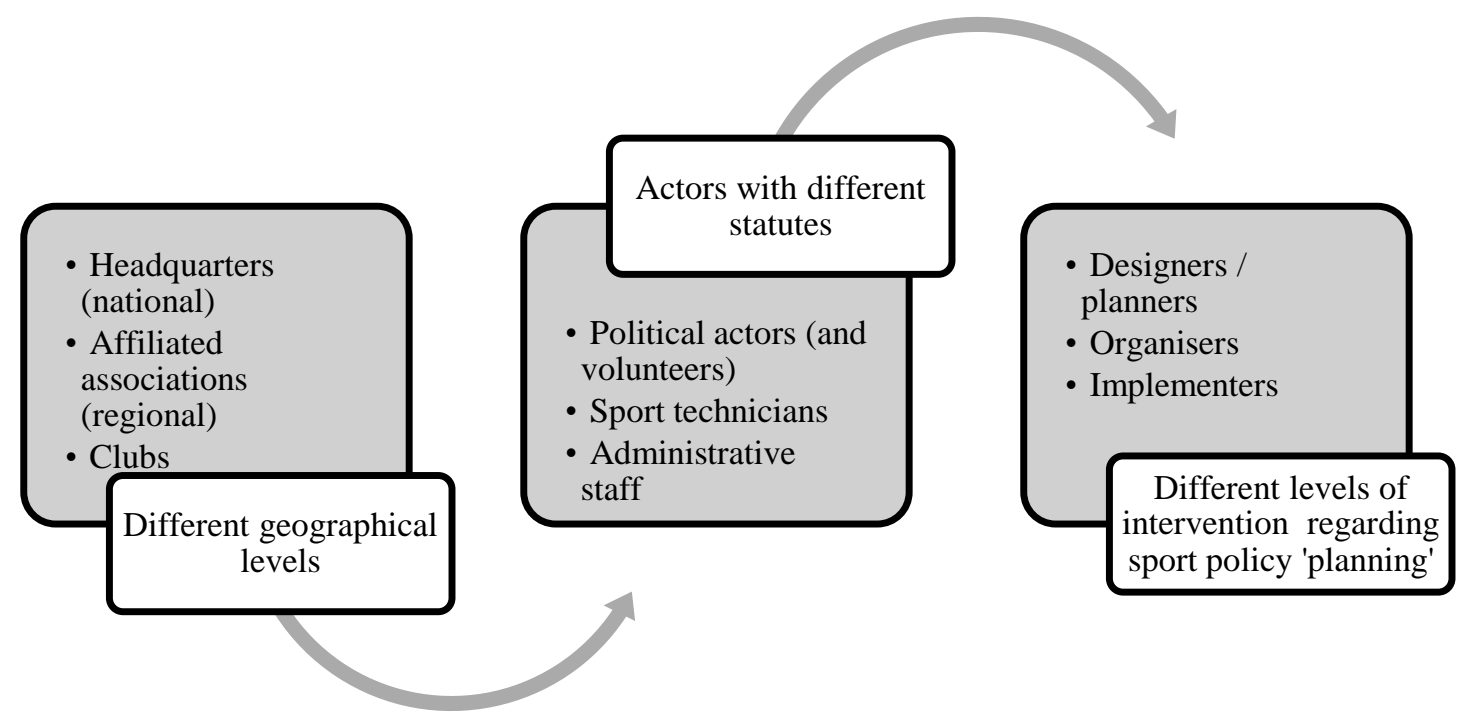

Figure 2. The NSF sport policy as the articulation of three interdependent dimensions.

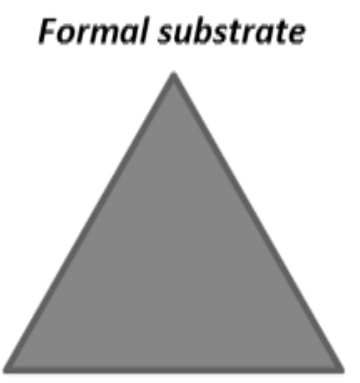

Simplified vision of the actors'

Managerial philosophy

role 
Figure 3. Actors" perceptions about the "formal substrate" dimension: main categories of agreements and/or controversies.

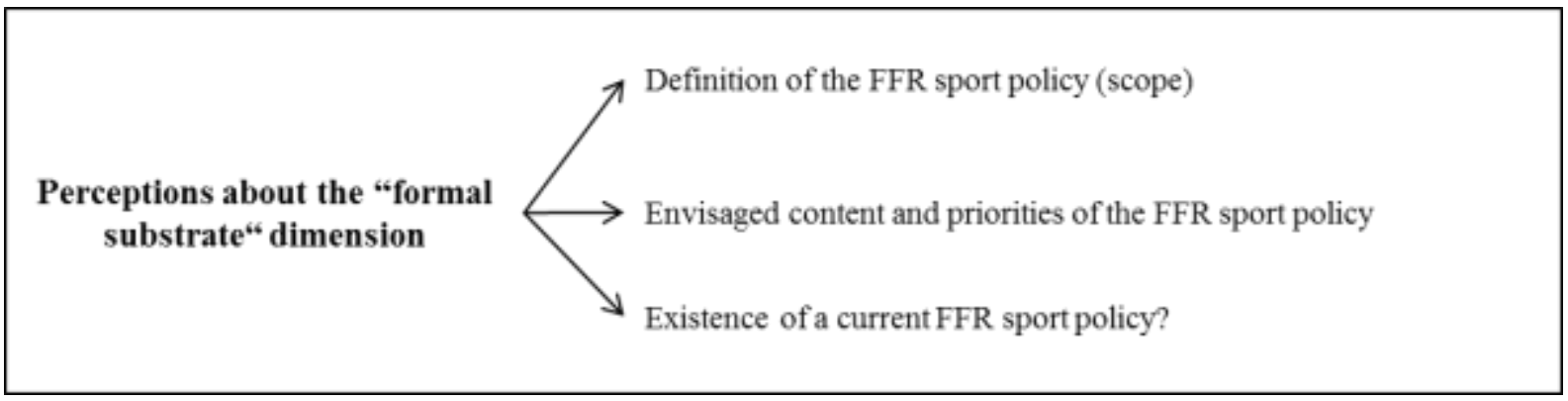

Figure 4. Actors' perceptions about the 'managerial philosophy' dimension.

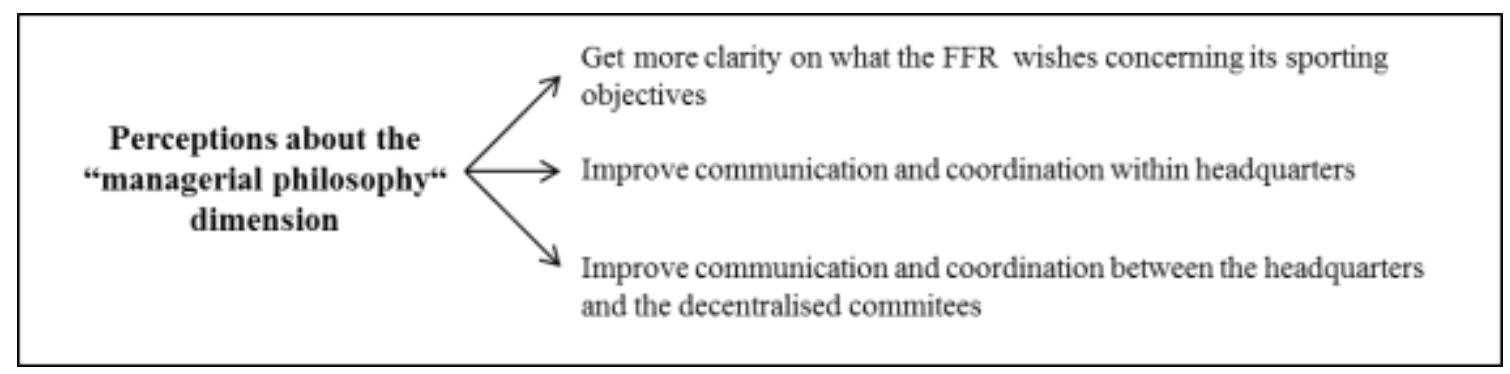

Figure 5. Actors' perceptions about the roles of the actors and their relations.

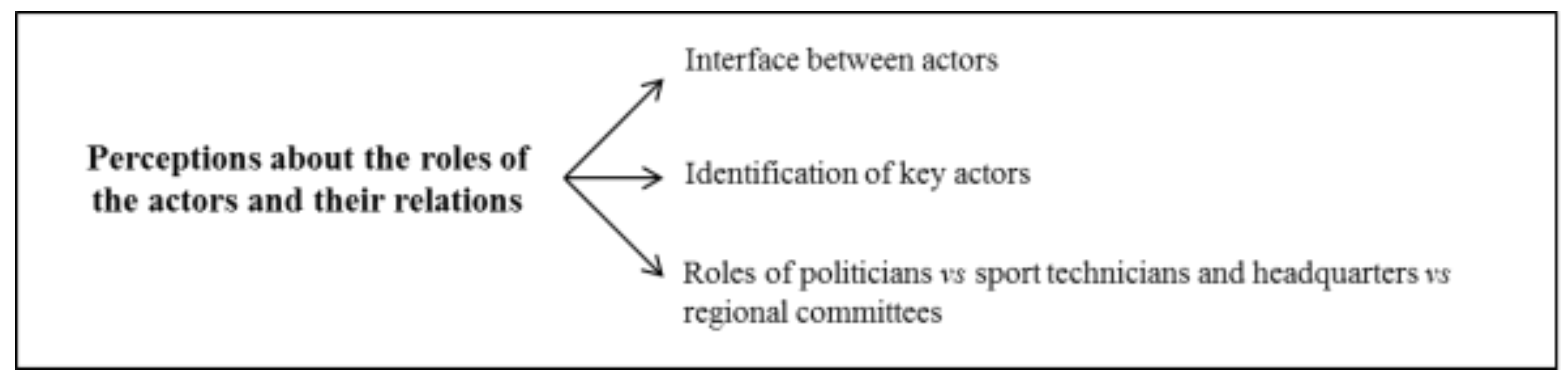

